\title{
Platform Economy and Liability Questions - Desperately in Search of Concepts Lost in the Virtual World or "Störerhaftung" Resurrected?
}

\author{
Karl-Nikolaus Peifer
}

Published online: 30 August 2017

(C) Max Planck Institute for Innovation and Competition, Munich 2017

The question of who is infringing rights and who is merely enabling an infringement by others is highly relevant for the so-called "platform economy". It refers to auctioneers presenting goods protected by trademarks (eBay), to search engine providers, and to platforms that provide access to information of all kinds.

One aspect of this topic is provider responsibility. This area is vibrant in the field of public communication of works in copyright law. The jurisdiction of the Court of Justice of the European Union (CJEU) in this field has been criticized as erratic. In reality, the Court uses basically two prerequisites in establishing whether an actor is actively communicating or merely passively providing access to third-party content: (1) some sort of activity by an intermediary is needed to make one become an actor; and (2) a new public has to be reached either by addressing so-far unlicensed users or by using a new technology to reach recipients.

CJEU case law classifies simple linking to works being communicated via Internet services as passive and licit behavior $\left(\right.$ Svensson $\left.^{1}\right)$. The same is true for the framing of content in a YouTube channel originally stored on another website $\left(\right.$ BestWater $\left.^{2}\right)$. The linking of illegal content which has been put on an Internet service without a license is considered to be illicit activity (GS Media ${ }^{3}$ ). Communication of works into the waiting room of a doctor's practice is active

\footnotetext{
${ }^{1}$ CJEU, Case No. C-466/12, Nils Svensson, Sten Sjögren, Madelaine Sahlman and Pia Gadd v. Retriever Sverige AB, 45(4) IIC p. 466 (2014), doi:10.1007/s40319-014-0210-2.

2 CJEU, Case No. C-348/13, BestWater International GmbH v. Michael Mebes and Stefan Potsch, 46(3) IIC p. 362 (2015), doi:10.1007/s40319-015-0326-z.

3 CJEU, Case No. C-160/15, GS Media BV v. Sanoma Media Netherlands BV, Playboy Enterprises International Inc., and Britt Geertruida Dekker, 48(3) IIC p. 342 (2017), doi:10.1007/s40319-017-0575-0.
} 
but not considered to reach a sufficiently wide public $\left(S C F^{4}\right)$. The communication via television in a sport rehabilitation center or in a hotel room is both active behavior and it reaches a new public (Reha Training ${ }^{5}$ and $S G A E^{6}$ ). File hosting services are considered to be copyright violators if they promote links to illegal content (Ziggo/Pirate $\left.B a y^{7}\right)$. There are two types of explanations for this jurisdiction.

Firstly, the CJEU as an international court is more inclined to solve a case by its outcome than by the perfect fit with existing rules and liability concepts of Member States. However, there is a system that can be derived from the cases: the decisions are hostile to illegal content being linked, framed or uploaded, and they are friendly to communicators who merely facilitate recipients' attention to what is already (legally) there.

Secondly, there is also a guiding line: the E-Commerce Directive of 2000 tried to build a "superhighway" for information service providers with lenient or no liability risks. This is also an outcome, not a method. Privileges are filters, not legal concepts. Legal rules which have to be built around this (desired) outcome leave questions and gaps which have led to strategic behavior: providers who fit into the definition of privileged entities have grown within the liability gap, while traditional industry and media companies have to queue up on narrow roads well protected by risk controllers and stiff rules. Traditional industry speaks of a "value gap", which is suspected to be shifted to the new players. Indeed, the E-Commerce privileges have strengthened participants who develop information tools and refrain from producing information in favor of comfortable customer experiences by sorting, listing and presenting third-party content through algorithmic methods. This strategy has provided the new players with some type of active control over how platforms work and how they are used.

Courts reacted to that shift of power by using traditional concepts and making them fit into the system of privileges. What are the tools for such realignment? Whereas the E-Commerce Directive is friendly to passive behavior (enabling access, hosting and mere user activities) this friendliness ends wherever the intermediary shifts from passive enabling to actively influencing information or its presentation. The CJEU has taken up this tool wherever substantive legal provisions left room for defining who is an actor and who is a passive provider. This is especially true for the notion of public communication, a term not defined in the Information Society Directive. YouTube is still considered as being passive as long as it merely offers platform space, Pirate Bay, however, is active because it provides

\footnotetext{
${ }^{4}$ CJEU, Case No. C-135/10, Società Consortile Fonografici (SCF) v. Marco Del Corso, and Procuratore generale della Repubblica, 43(8) IIC p. 959 (2012).

${ }^{5}$ CJEU, Case No. C-117/15, Reha Training Gesellschaft für Sport- und Unfallrehabilitation mbH v. Gesellschaft für musikalische Aufführungs- und mechanische Vervielfältigungsrechte eV (GEMA), 48(1) IIC p. 97 (2017), doi:10.1007/s40319-016-0550-1.

${ }^{6}$ CJEU, Case No. C-306/05, Sociedad General de Autores y Editores de España (SGAE) v. Rafael Hoteles SA, Case No. C-306/05.

${ }^{7}$ CJEU, Case No. C-610/15, Stichting Brein v. Ziggo BV and XS4ALL Internet BV, doi:10.1007/s40319017-0628-4
} 
links. Hotels and fitness centers are active if they put up equipment communicating content.

The same system slowly slips into media law. Search engine providers are passive as long as they help to find content. If they take active steps to influence what the user searches (by autocomplete algorithms), their role shifts to active behavior. Data protection laws (gaining strong influence on the publication and distribution of information) consider them to be responsible even for information not searched but indicated by the search mechanism (Google Autocomplete ${ }^{8}$ ); the search engine provider becomes the publisher or at least the (intellectual) distributor of content. Algorithms which make available what has been deeply buried in the archives of content providers are also considered to represent active behavior if they provide links (actively put up by the algorithmic mechanisms) to infringing content (Google Spain ${ }^{9}$ ).

Activity therefore is the key term for the new media order and may become a leading concept for the platform economy as such. Courts interpret this concept with a tendency toward result-oriented reasoning. Legislators are tempted to nudge providers to license merely facilitating activity. ${ }^{10}$ The time has come to think about the development of a new concept, such as the German "Störerhaftung" (i.e. interferer or inducer responsibility). In Germany this has worked as a toolkit to reach a compromise between infringement liability and mere responsibility for the facilitation of a third-party infringement. What is the charm of the concept? It becomes active merely upon notice. It calls for reaction, not for compensation. It is not about liability - not even accessory liability - but it is about the responsibility to terminate a certain activity. ${ }^{11}$ It merely ends inducements, which lead to direct and concrete infringements (i.e. by the deletion of links). German courts like this toolkit possibly exactly because of this result. Even the CJEU has found some charm in using it $\left(M_{c F a d d e n^{12}}\right)$. Could it also be a model for a European Directive? Could it even be suitable to put up certain statutory intervention duties to new intermediaries outside copyright law, such as UBER or Airbnb? At minimum it might be a bad idea to abandon the concept too quickly as is suggested by German doctrine (and some courts).

\footnotetext{
${ }^{8}$ German Federal Supreme Court, Case No. VI ZR 269/12 - Google Autocomplete.

9 CJEU, Case No. C-131/12, Google Spain SL, Google Inc. v. Agencia Española de Protección de Datos (AEPD), Mario Costeja González, Case No. C-131/12, ECLI:EU:C:2014:317.

10 See Art. 13 Draft of a Copyright Directive, COM [2016] 593 final.

11 See Art. 12 subsection 3 E-Commerce Directive.

12 CJEU, Case No. C-484/14, Tobias Mc Fadden v. Sony Music Entertainment Germany GmbH, 48(1) IIC pp. 92-93 (2017), doi:10.1007/s40319-016-0548-8.
} 